\title{
Downscaling land surface temperature on multi-scale image for drought monitoring
}

\section{A. Sediyo Adi Nugraha, Totok Gunawan, Muhammad Kamal}

A. Sediyo Adi Nugraha, Totok Gunawan, Muhammad Kamal, "Downscaling land surface temperature on multi-scale image for drought monitoring," Proc. SPIE 11311, Sixth Geoinformation Science Symposium, 113110A (21 November 2019); doi: 10.1117/12.2544550

EDIE Event: Sixth Geoinformation Science Symposium, 2019, Yogyakarta, Indonesia 


\title{
Downscaling Land Surface Temperature on Multi-Scale Image for Drought Monitoring
}

\author{
A Sediyo Adi Nugraha ${ }^{\mathrm{a}, \mathrm{b}}$, Totok Gunawan ${ }^{\mathrm{c}}$, Muhammad Kamal ${ }^{\mathrm{c}}$ \\ aPostgraduate Program of Remote Sensing, Faculty of Geography, Universitas Gadjah Mada, \\ Yogyakarta, Indonesia; ${ }^{b}$ Geography Education Study Program, Department of Geography, Faculty \\ of Law and Social Science, Universitas Pendidikan Ganesha, Bali, Indonesia, email: \\ adi.nugraha@undiksha.ac.id; ' Department of Geography Information Science, Faculty of \\ Geography, Universitas Gadjah Mada, Yogyakarta, Indonesia. email: m.kamal@ugm.ac.id
}

\begin{abstract}
Land Surface Temperature (LST) is an important indicator of environmental changes, especially related drought monitoring. It is necessary to accurately detect drought events using advanced technology proved information regarding the drought areas. Remote sensing images have proven to be efficient in detecting drought events. MODIS Terra and Landsat 7 ETM+ (Enhanced Thematic Mapper Plus) and Landsat 8 OLI/TIRS (The Operational Land Imager and the Thermal Infrared Scanner) represent remote imaging images with different spatial resolutions that enable us to provide drought information. However, proper methods are needed to optimize these images for monitoring drought events. The purpose of this study is to find out the ability of multi-scale images provide information about drought monitoring using LST methods. The method used in LST is a Temperature Condition Index (TCI), the Crop Water Stress Index (CWSI), and Principal Component Analysis (PCA). All three equations are selected because they represent a modification of the method for LST input. The results suggest that the three equations used in multi-level imagery have a critical alignment of information regarding the drought. The results show that the drought pattern identified by MODIS Terra image was similar to the one detected by Landsat ETM+ and OLI/TIRS images. However, we found a temperature difference in the dry season (especially in October) between Landsat ETM+ and OLI/TIRS. The degree of LST estimation accuracy between MODIS Terra and Landsat (ETM+ and OLI/TIRS) is indicated by the average difference between the results of those images, which was 1 degree Celsius $\left(1^{\circ} \mathrm{C}\right)$. The use of these three equations for drought monitoring with multi-level imagery suggests that there is a positive relationship. This relationship manifests the same pattern, shape, and association that are produced, thus using a common equation for drought monitoring is more focused.
\end{abstract}

Keywords: MODIS Terra, Landsat ETM+, Landsat 8 OLI/TIRS, TCI, CWSI, PCA

\section{INTRODUCTION}

The Difference in surface temperature is the impact of natural changes due to certain phenomena such as El-Nino / La-Nina. Changes in surface temperature can also occur due to very large land-use changes in a given area [1,2]. Variations in land surface temperature can be measured with the help of remote sensing technology as a medium for estimating the conditions affected by land surface temperatures such as evaporation, soil moisture, droughts, and vegetation stress levels [3-7]. Current rapid technological developments can measure Land Surface Temperatures (LST) for drought monitoring using thermal infrared wavelengths such as the Moderate-resolution Imaging Spectroradiometer (MODIS) and LandSatellite (Landsat) [8-15]. Landsat has more detailed capabilities at spatial resolutions than fashion, so both provide more detailed information regarding droughts $[16,17]$. MODIS image capabilities are regional and help in spatial and temporal detection for drought detection and later information was clarified with Landsat for drought conditions.

Utilization of satellite imagery in monitoring drought is required, but the higher spatial resolution is required as support to know the location distribution due to drought. Multi-scale imagery is one of the things that can be used to monitor drought by using appropriate methods in utilizing information from satellite imagery, so the land surface temperature can be used as one of the determinants for drought monitoring. Son et al. [11] in his research explains that there is still a difference between the results of data processing on the territorial conditions especially meteorological conditions. These differences come from land parameters such as land cover, slope, and Available Water Capacity (AWC) [18]. The cause of the drought in the form of significant weather changes leads to an increase in temperature to some

Sixth Geoinformation Science Symposium, edited by Sandy Budi Wibowo, Andi B. Rimba

Stuart Phinn, Ammar A. Aziz, Proc. of SPIE, Vol. 11311, 113110A · ( 2019 SPIE

CCC code: $0277-786 \mathrm{X} / 19 / \$ 21 \cdot$ doi: $10.1117 / 12.2544550$ 
degree and result in increased evaporation on the land and also the plants [19]. Based on the condition, the surface temperature can be used as a single parameter in the determination of drought. The multi-scale approach needed to know drought conditions with large area and given information more precise than using one image. That condition can decrease the impact of drought in a region and made a mitigation disaster of drought. Remote sensing method is important to support multi-scale ability with an algorithm such as TCI, CWSI, and PCA in detecting a drought $[13,20,21]$. Are methods represents condition from meteorology, vegetation stress, and thermal energy from the compartments method to optimize capability, multi-scale to detect droughts [13,20,22-28].

Multi-scale research supposed to becomes methods for detecting drought monitoring. Furthermore, the multi-scale method can be a determination to one of a method for detecting drought. The aims of this research are to know the multiscale capability of detecting drought with three algorithms and chosen one best method to use for detecting drought monitoring. This research not only gives monitoring but can prove a thorough evaluation of the field condition of a region.

\section{STUDY AREA AND DATA}

\subsection{Study Area}

East Java Province lies in $111^{\circ} 0$ 'to $114^{\circ} 4^{\prime}$ ' East Longitude, and $7^{\circ} 12$ 'to $8^{\circ} 48^{\prime}$ South Latitude. The total area of East Java Province reaches 46,428 square kilometers, divided into four regional coordination bodies (Bakorwil), 29 districts, nine cities and 658 sub-districts with 8,457 villages (2,400 urban villages and 6,097 villages) [29]. The research was conducted in East Java province in Tuban, Probolinggo, and Surabaya. Those areas are chosen because they often suffer from drought conditions caused by EL-Nino anomaly resulting in an increase in surface temperature. Changes in land cover during wet and dry seasons have significant differences that affect changes in surface temperatures in each region [1]. The difference in change is an interesting condition to know the difference in surface temperature conditions in the area. Increasing the surface temperature can be one factor for the occurrence of drought.

\subsection{Remote Sensing Data}

$L S T$

The MODIS and Landsat data product can be obtained for free on NASA official website http://ladsweb.nascom.nasa.gov/data/search.html and http://usgs.gov/. MODIS data used product Terra image for extraction LST and for Landsat image used product Landsat 7 ETM+ and Landsat 8 OLI/TIRS. MODIS Terra image period used from October to March from 2002 to 2015 (Table 1) because that time has an El-Nino phenomenon and has an impact on a crop field, then it saw the phenomenon in the dry season and wet season. Similar to the MODIS Terra period used for Landsat image from October to March from 2002 to 2015 (Table 2) because of having the El-Nino phenomenon. Landsat image selection data scene based on cloud cover condition is below 5\%. Each Landsat image has a different recording that will affect the change in Land Surface Temperature (LST). Extraction LST methods for MODIS Terra using an algorithm developed by Li and Becker [30]. Different from MODIS Terra, Landsat image using two algorithms for extraction LST because Landsat $7 \mathrm{ETM}+$ using one single channel (Band 6.2/high gain) and Landsat 8 OLI/TIRS have two-channel (band 10 and 11). The algorithm developed by Qin et al. [31] for extraction Landsat 8 OLI/TIRS and Landsat 7 ETM+ using an algorithm developed by USGS [17].

The Landsat 7 ETM+ has condition striping data (missing on scan line) and different with Landsat 8 OLI/TIRS with full covered. For this research that condition was not to fixed stripping data in Landsat 7 ETM+ because part of the study area has enough to use. If striping data in Landsat $7 \mathrm{ETM}+$ must be fixed give influencing processing data and result differently. The result is not actually from one image in Landsat 7 ETM + and can't for validation and processing Land Surface Temperature. 
Table 1. The number of Daily MODIS Images.

\begin{tabular}{|c|c|c|c|c|}
\hline No & Years & Month & Date & Total Image \\
\hline \multirow{3}{*}{1} & \multirow{3}{*}{2002} & October & $1,3,8,10,12,17,19,21,26$ & 9 \\
\hline & & November & $7,8,14,16$ & 4 \\
\hline & & December & $6,15,18,20$ & 4 \\
\hline \multirow{3}{*}{2} & \multirow{3}{*}{2003} & January & 14,16 & 2 \\
\hline & & February & Full Cloud & 0 \\
\hline & & March & $12,23,30$ & 3 \\
\hline \multirow{3}{*}{3} & \multirow{3}{*}{2009} & October & $6,11,15,18,22,29$ & 6 \\
\hline & & November & $1,3,5$ & 3 \\
\hline & & December & $3,7,16$ & 3 \\
\hline \multirow{3}{*}{4} & \multirow{3}{*}{2010} & January & Full Cloud & 0 \\
\hline & & February & 9,11 & 2 \\
\hline & & March & $8,13,15,22$ & 4 \\
\hline \multirow{3}{*}{5} & \multirow{3}{*}{2014} & October & $9,11,13,19,27,31$ & 6 \\
\hline & & November & $1,3,5$ & 3 \\
\hline & & December & Full Cloud & 0 \\
\hline \multirow{3}{*}{6} & \multirow{3}{*}{2015} & January & 6,24 & 2 \\
\hline & & February & $5,16,18$ & 3 \\
\hline & & March & $18,29,31$ & 3 \\
\hline
\end{tabular}

Source: http://ladsweb.nascom.nasa.gov/data/search.html.

Table 2. Landsat Image Scene used in the Study.

\begin{tabular}{|c|c|c|}
\hline Year & Date-Month of Recording & Landsat Image Type \\
\hline \multirow{2}{*}{2002} & October 1 & ETM+ \\
\cline { 2 - 3 } & November 11 & ETM+ \\
\hline \multirow{2}{*}{2003} & January 14 & ETM+ \\
\cline { 2 - 3 } & March 19 & ETM+ \\
\hline \multirow{2}{*}{2009} & October 29 & ETM+ (Stripping) \\
\cline { 2 - 3 } & November 30 & ETM+ (Stripping) \\
\hline \multirow{2}{*}{2014} & October 3 & OLI \\
\cline { 2 - 3 } & November 4 & OLI \\
\hline 2015 & January 7 & OLI \\
\hline
\end{tabular}

Source: http://usgs.gov/

\section{METHODOLOGY}

Multi-scale remote sensing data in this research is using primary data because directly synthesized from imagery. The multi-scale remote sensing data must be scaled and standardized for drought parameters. Flowchart research can be shown in the figure. 1.

\subsection{Land Surface Temperature Extraction}

$M O D I S$

MODIS Terra image used band 31 and 32 spectral radiance for extraction LST. Before processing to LST, it must be processed to Brightness Temperature (BT) with equation (1). Then the algorithm for LST used equation (2) developed by $\mathrm{Li}$ and Becker [30]. Thus the algorithm applied to NOAA image has a good correlation with the atmospheric condition and has a small gap with the condition in field survey [30]. The series of MODIS Terra image must be compiled to be one month to know how full condition and it has the same condition with Landsat if thus the image to derive as the location of drought monitoring. 


$$
T_{b}=\frac{C 2}{\left(V i * \ln \left(\frac{C 1}{\left.V i^{5} * \text { radians } i\right)+1}\right)\right)}
$$

Where $\mathrm{Tb}$ is the brightness temperature $(\mathrm{K})$ form band 31 and $32 ; \mathrm{C} 1$ and $\mathrm{C} 2$ are constant radiance $\left(\mathrm{C} 1=1.1910659 \times 10^{8}\right.$ $\left.\left[\mathrm{W} \mathrm{m}{ }^{-2} \mathrm{sr}^{-1}\left(\mu \mathrm{m}^{-1}\right)^{-4}\right] ; \mathrm{C} 2=1.438833 \times 10^{4}[\mathrm{~K} \mu \mathrm{m}]\right)$; vi is central wavelength can be obtained from MODIS L1B ATBD for band 31 and 32 [32].

$$
T_{S}=A_{0}+P \frac{T_{4}+T_{5}}{2}+M \frac{T_{4}-T_{5}}{2}
$$

Where Ts is land surface temperature $(\mathrm{K}) ; \mathrm{A}_{0}$ used 1274 then $\mathrm{P}$ and $\mathrm{M}$ used more algorithms shown below in equation (3) and (4).

$$
\begin{aligned}
& \mathrm{P}=1+0.15616 \frac{1-\varepsilon}{\varepsilon}-0.482 \frac{\Delta \varepsilon}{\varepsilon^{2}} \\
& \mathrm{M}=6.26+3.98 \frac{1-\varepsilon}{\varepsilon}+38.33 \frac{\Delta \varepsilon}{\varepsilon^{2}}
\end{aligned}
$$

Where $\varepsilon$ values of emissivity can be obtained using equation (5);

$$
\varepsilon=\frac{\varepsilon_{1}-\varepsilon_{2}}{2}, \Delta \varepsilon=\varepsilon_{4}-\varepsilon_{5}
$$

Where $\varepsilon_{4}$ and $\varepsilon_{5}$ are emissivities that can be obtained from Handbook MODIS L1B ATBD [32].

Landsat

Extraction Landsat imagery for land surface temperature similar to MODIS, first extract to brightness temperature values, especially Landsat 7 ETM+ (equation (6) - (7)) for land surface temperature. Landsat 8 OLI/TIRS used extraction to compare from Sobrino's Split-Window Algorithm (SWA-S) to get water vapor values (equation (8)) and Qin's SplitWindow Algorithm (SWA-Q) for land surface temperature.

$$
\begin{aligned}
T_{\text {rad }} & =\frac{K_{2}}{\ln \left(\frac{K 1}{L_{\text {sensor }}}+1\right)} \\
T_{\text {kin }} & =\varepsilon^{1 / 4} * T_{\text {rad }}
\end{aligned}
$$

Where Trad is the brightness temperature $(\mathrm{K}) ; \mathrm{K}_{1}$ and $\mathrm{K}_{2}$ are constants can be obtained from Landsat 7 handbook [17]; $\mathrm{L}_{\text {sensor }}$ is spectral radiance from band thermal Landsat 7 ETM+; Tkin is temperature kinetic form Landsat 7 ETM+ and that is the real temperature of object for land surface temperature. Landsat 8 OLI/TIRS has a different algorithm with Landsat 7 ETM+ because having many algorithms to obtain land surface temperature with Qin's Split-Window Algorithm methods (SWA-Q). Parameters including such as brightness temperature, water vapor, atmospheric transmittance, and emissivity as equation (9) - (16).

$$
\begin{gathered}
\mathrm{W}=\mathrm{f}_{17} * W_{17}+\mathrm{f}_{18} * W_{18}+\mathrm{f}_{19} * W_{19} \\
T_{s}=A_{0}+A_{1} T_{10}+A_{2} T_{11} \\
A_{0}=E_{1} a_{10}+E_{2} a_{11} \\
A_{1}=1+A+E_{1} b_{10} \\
A_{2}=A+E_{2} b_{11} \\
\mathrm{~A}=D_{10} / E_{0} \\
E_{1}=D_{11}\left(1-C_{10}-D_{10}\right) / E_{0} \\
E_{2}=D_{10}\left(1-C_{11}-D_{11}\right) / E_{0} \\
E_{0}=D_{11} C_{10}-D_{10} C_{11}
\end{gathered}
$$

Where $\mathrm{W}$ is total water vapor from spectral radiance MODIS Terra; $\mathrm{f}$ is weighting functions from MODIS level 2; $W_{x}$ is water vapor from spectral radiance MODIS band 17, 18, and 19. All of the processing to obtain water vapor (w) using MODIS imagery For Ts is the LST $(\mathrm{K}) ; \mathrm{T}_{10}$ and $\mathrm{T}_{11}$ are brightness temperature of band 10 and band 11 Landsat 8 OLI/TIRS; $C_{i}$ and $D_{i}$ are parameters of the band 10 and 11 from Landsat 8 OLI/TIRS; $A_{0}, A_{1}, A_{2}, E_{1}, E_{2}, E_{0}$, and $A$ are parameters then $\mathrm{a}_{10}, \mathrm{a}_{11}, \mathrm{~b}_{10}$, and $\mathrm{b}_{11}$ are coefficient all of them can be obtained in Rozenstein et al. [33] and Nugraha [15]. 


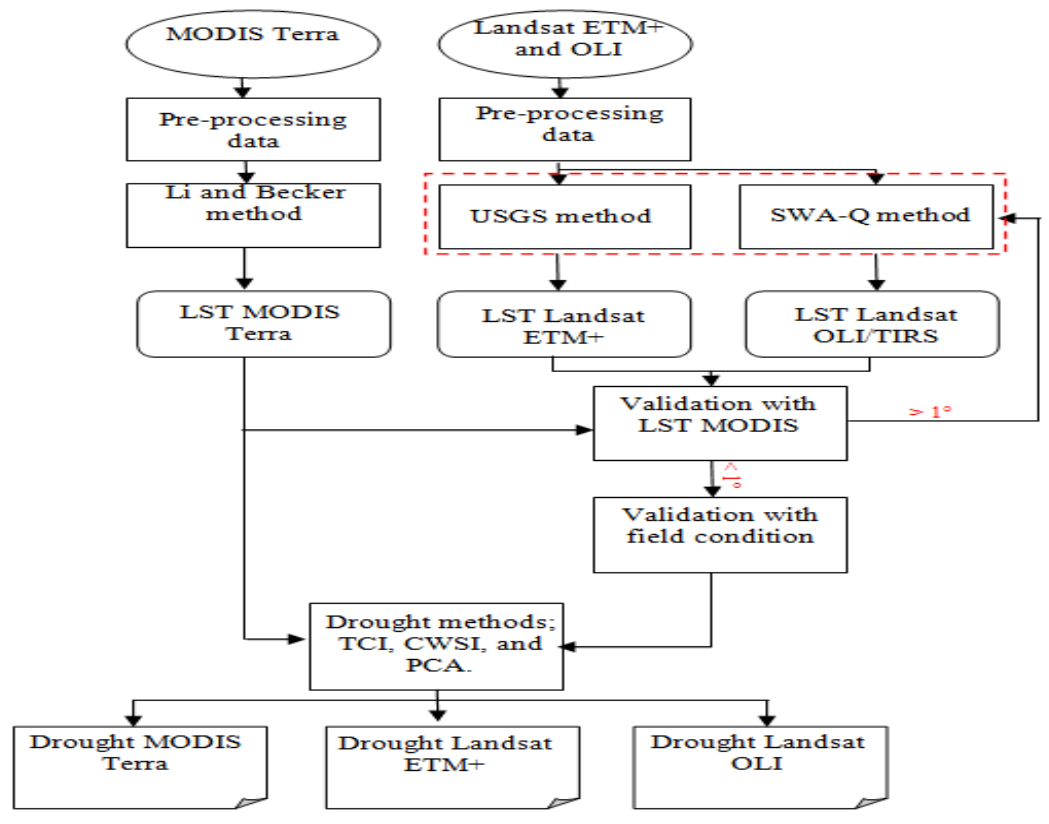

Figure 1. Flowchart of The Multi-scale research.

\subsection{Temperature Condition Index (TCI)}

Analysis drought from Temperature Condition Index (TCI) can explain about vegetation stress and increase accuracy from band thermal $[34,35]$. This algorithm has good information about drought monitoring if used with time-series data and has a similar index with the Vegetation Condition Index (VCI) [13,34]. Assumes with this algorithm the vegetation stress will be increasing high temperature and decrease condition soil moisture [13]. This index has ranged values about $0-1$, where 0 is condition wet and 1 is condition dry. Input values this index all from an image like $\mathrm{LST}_{\max }$ and $\mathrm{LST}_{\min }$ and algorithm expressed using equation (17).

$$
\mathrm{TCI}=\frac{L S T_{\max }-L S T}{L S T_{\max }-L S T_{\min }}
$$

\subsection{Crop Water Stress Index (CWSI)}

This index has a relation to moisture condition and thermal data from remote sensing only represents the condition, temperature of the canopy $[11,36]$. The condition with this algorithm is surface temperature has restricted with full canopy condition and just equal canopy is has represented surface temperature [37]. However, this index has a strong correlation is used time-series data for detecting drought monitoring for agricultural. The algorithm expressed using equation (18).

$$
\text { CWSI }=\frac{L S T-L S T_{\min }}{L S T_{\text {max }}-L S T_{\text {min }}}
$$

Where $\mathrm{LST}_{\min }$ and $\mathrm{LST}_{\max }$ is a maximum and minimum value from LST; same with TCI for value range this index is $0-1$ where 0 is wet and 1 is the dry condition.

\subsection{Principal Component Analysis (PCA)}

Principal Component Analysis (PCA) technique implements the multi-channel coordinate system and generates a new image with more information [38]. This technique can reduce minor information and the procedure used covariance matrix and eigenvalues, eigenvectors for all data and create new data with much information from the original data [11,39-41].

Remote sensing data for PCA used TCI, CWSI, and LST represent drought from meteorological, vegetation, and thermal infrared channel. Processing PCA used ENVI software to finish and the first PCA has high information more than $75 \%$ from all of the algorithms and it is a new drought with PCA [11]. The value of the range with PCA is the same as the other algorithm. 


\section{RESULTS}

\subsection{Land Surface Temperature Validation}

MODIS Terra and Landsat image have a different result about Land Surface Temperature (LST) for the condition in the dry season and the wet season. The difference can be seen in the figure. 2 beside cloud and shadow gave impact for LST result in both images such as increase or decrease the surface temperature around [42,43]. Landsat 7 ETM+ and MODIS Terra have difference patterns especially in the wet season (2008 - 2009), where Landsat has a high temperature in March but MODIS Terra in October (2009). This condition proved the methods of Li and Becker [30] has high accuracy, but Landsat 7 ETM+ has many factors influenced by before. Landsat $7 \mathrm{ETM}+$ for LST extraction it is represented from land cover emissivity and has value temperature range for one scene in one location with different topography is $300^{\circ}-325^{\circ} \mathrm{K}$ $\left(27^{\circ}-52^{\circ} \mathrm{C}\right)$. Landsat $8 \mathrm{OLI} / \mathrm{TIRS}$ proved with SWA-Q for extraction LST has a similar correlation with MODIS Terra and values or range for MODIS and Landsat is not more $1^{\circ}$. Nugraha [15] explain SWA-Q has a high accuracy between field survey and processing data and that proved in this result with MODIS Terra surface temperature. That condition, optimum if the value of water vapor can be found in MODIS and uses for the LST method [33]. In addition, the spatial resolution between MODIS and Landsat has an impact to know about the distribution of temperature is equal or different, but with pattern conditions, the surface temperature is identical (figure. 3 ).

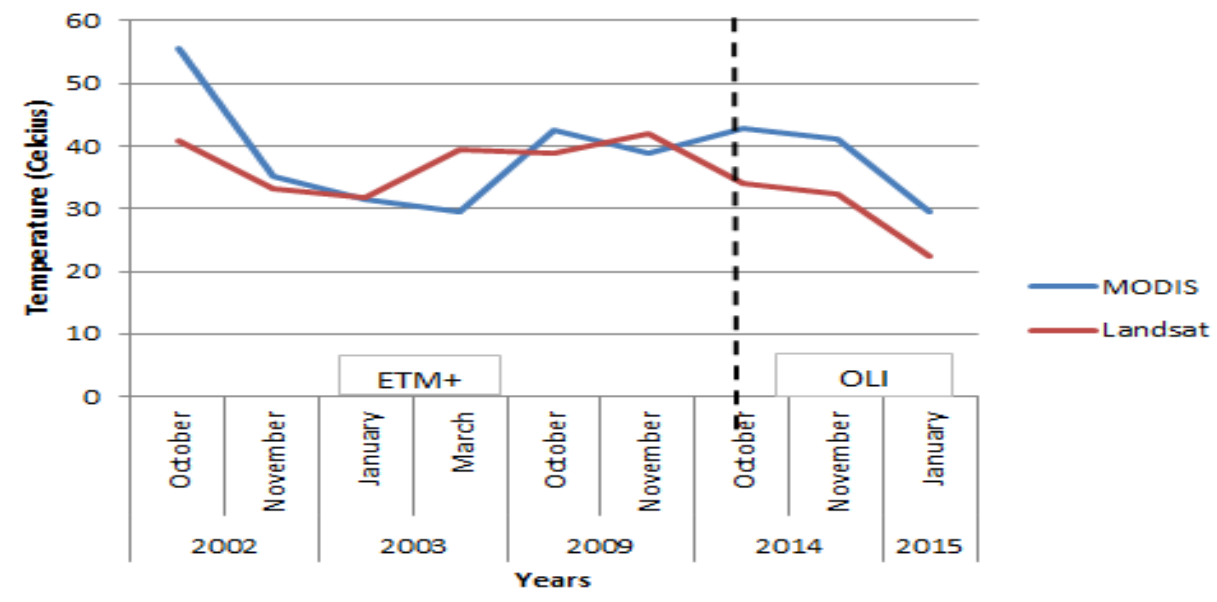

Figure 2. Graph of Temperature Difference between MODIS and Landsat image uses the average value data.

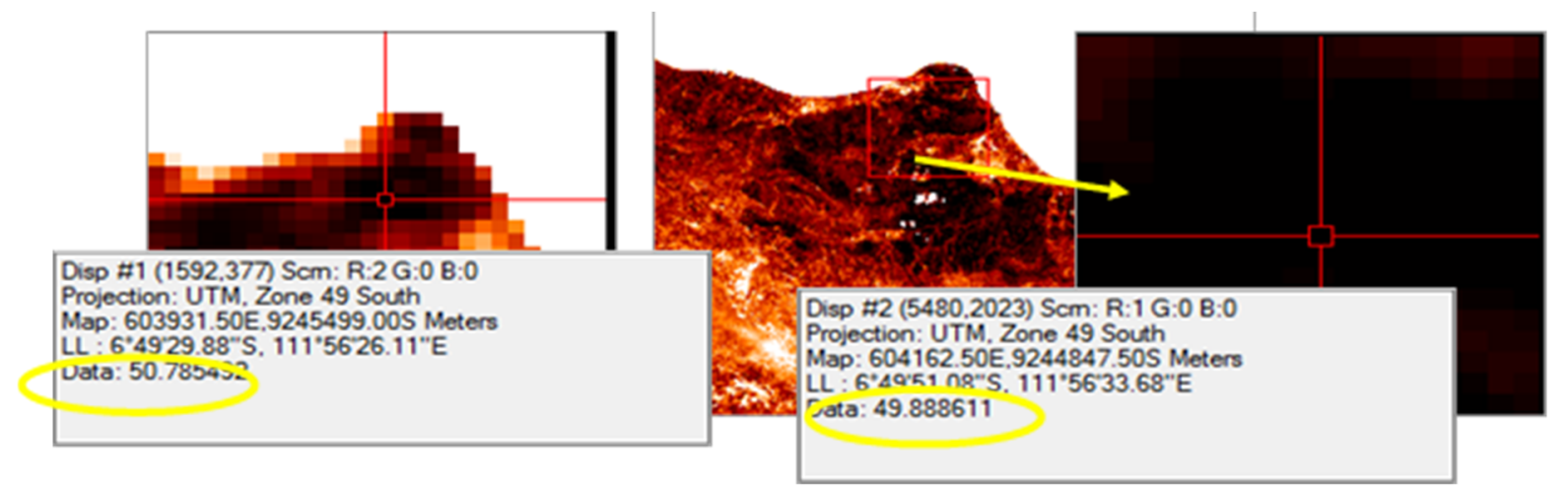

Figure 3. Comparison, Value Surface Temperature between MODIS Terra and Landsat.

Thus condition (figure. 3) cannot be evenly distributed on the overall scene image but has a dominant condition. The value of surface temperature is not high difference because of condition spatial resolution. With this proven multi-scale image to detecting drought with LST can be used. The important is the day of the image used must in the dry season to the optimal result of drought using LST methods. Compare with a condition object in the field such as asphalt, vegetation, soil, and water (figure. 4) proved surface temperature always increase from early morning to afternoon and decrease at evening. 

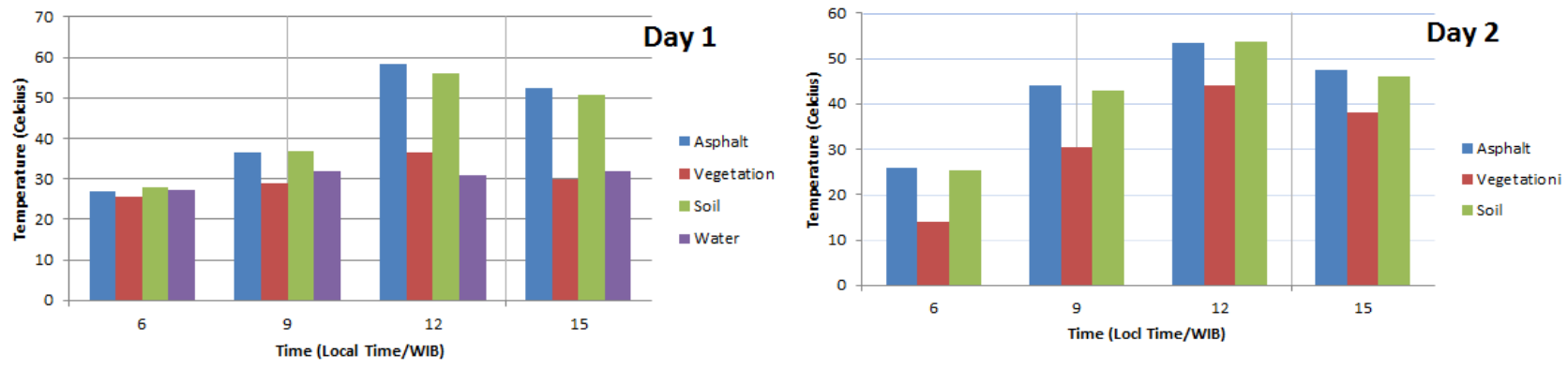

Figure 4. Graph of Surface Temperature Measurement in Field Survey

The best validation for LST in remote sensing it is the same time with image take a picture in location because the surface temperature in the field has boundary time to know how LST in that location [44]. The value surface temperature in the field is higher than the result of LST in an image because processing in an image has a reduce distraction such as atmospheric or sensor [45]. Figure. 4 shown day 1 and day 2 have a different temperature, that condition proved location to give impact about temperature. Surface temperature in the field is compared with the result of Landsat image especially, Landsat 8 OLI/TIRS because that reliable data with time survey. Surface temperature compares has given $1^{\circ}$ between the condition in the field and processing data. That difference occurs because the object observed in the field is directed and remote sensing image used pixel (spatial resolution) to processing data. That condition makes Landsat 8 OLI/TIRS has high accuracy to know the distribution of LST in some area.

\subsection{Drought Monitoring}

Analysis drought with three algorithms proved information on drought can be downscaling from multi-scale image. CWSI, TCI, and PCA for MODIS and Landsat have an equal pattern, association, and shape of drought information. MODIS more reliable for detecting drought information very fast than Landsat. Few information from MODIS to know the condition of the drought especially kind of drought because the spatial resolution to small. That situation makes downscaling information about drought need and Landsat can be alternative to know drought condition with Land Surface Temperature methods (figure. 4). 

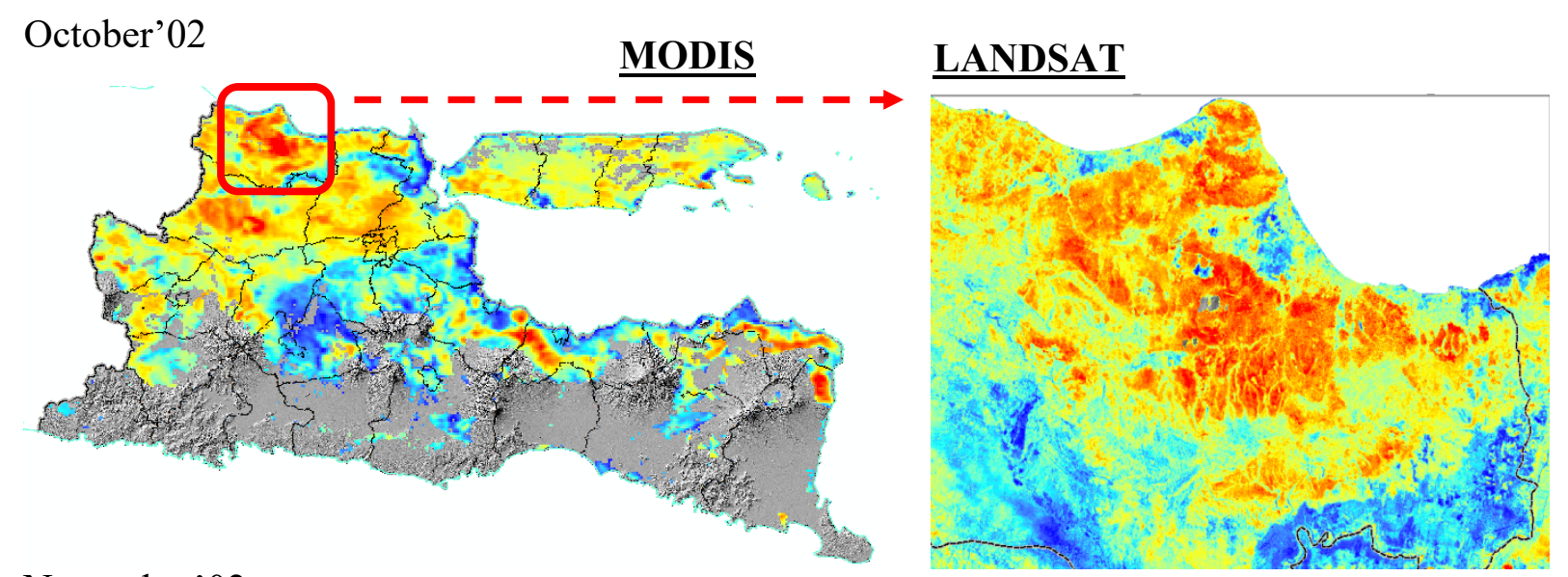

\section{November'02}
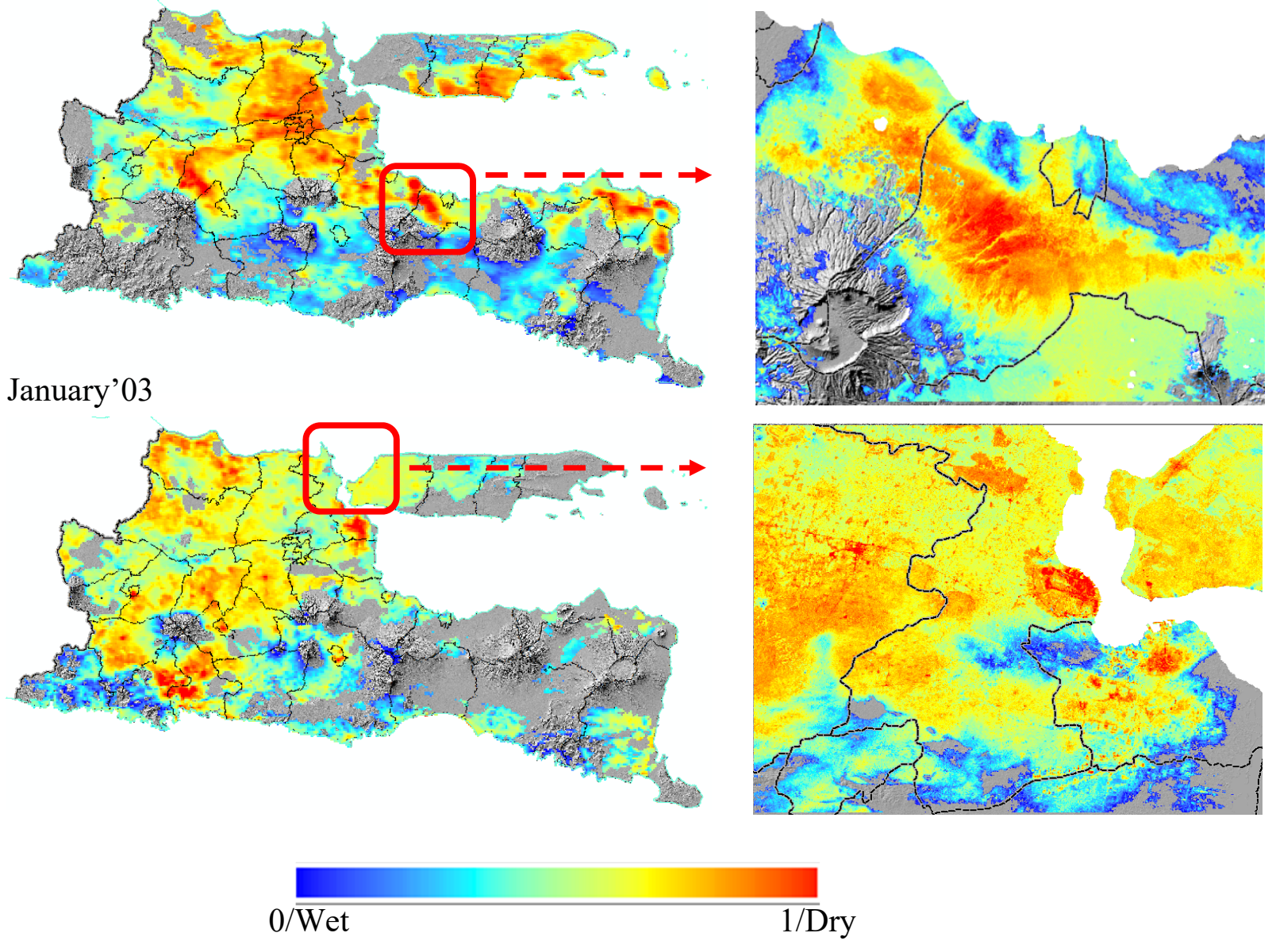

Figure 4. Result of TCI, CWSI, and PCA Processing on MODIS Terra and Landsat 7 ETM+ and Landsat 8 OLI/TIRS image of Dry month and Wet months.

Drought conditions in a dry month with an actual condition infield are the same location and distribution, but a wet month for MODIS and Landsat (January) has different conditions. MODIS indicated condition drought medium, but Landsat given different information about that area is drought. That condition influenced by the buildup area on Landsat because resolution 30 meters can be seen in more detail than resolution $1 \mathrm{~km}$. Differences with MODIS processing data Landsat 
given unpredictable result. Processing data for CWSI, TCI and PCA for Landsat 7 ETM+ and Landsat 8 OLI/TIRS not optimized because the result indicated drought on same (figure. 5).

\section{LANDSAT}
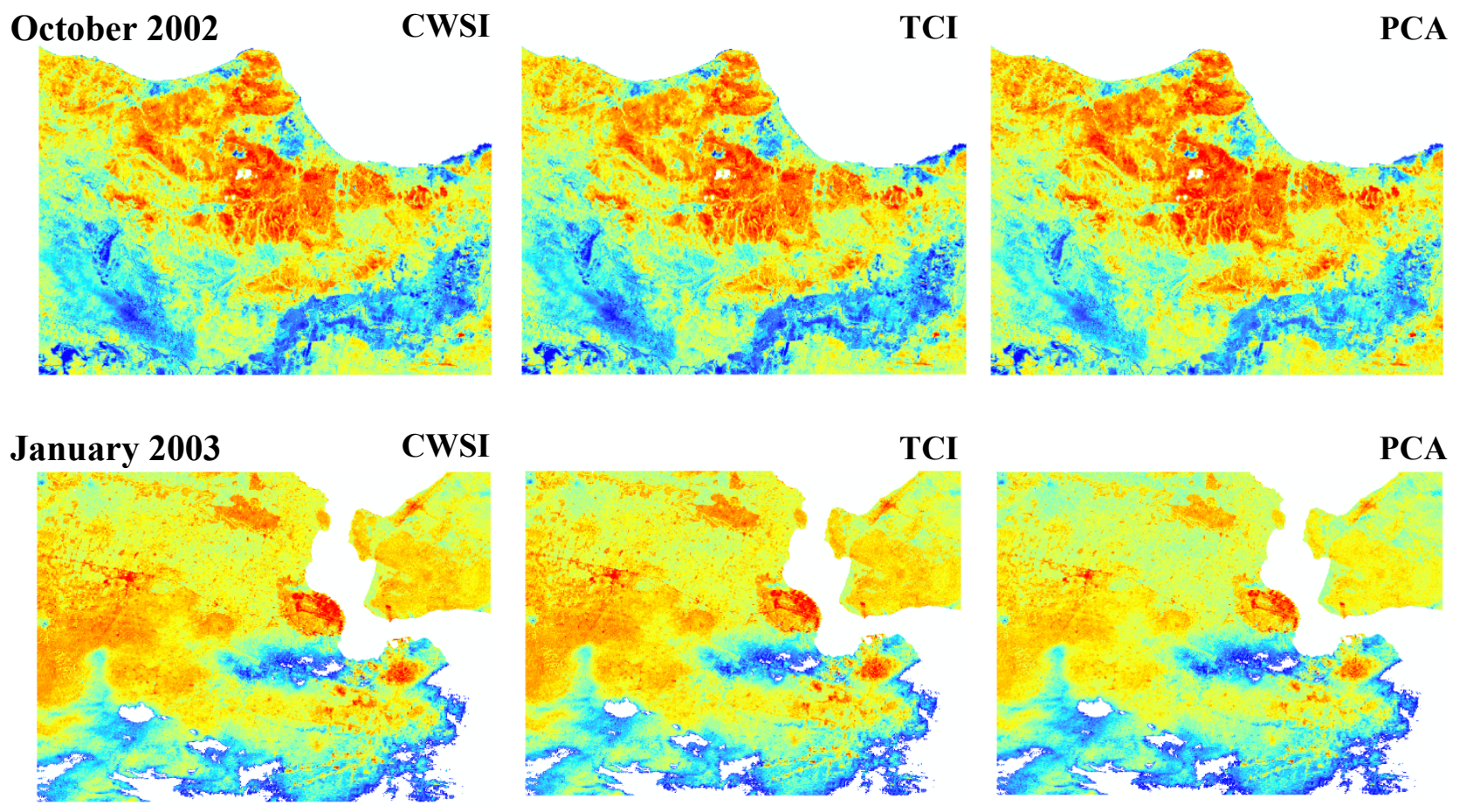

October 2009

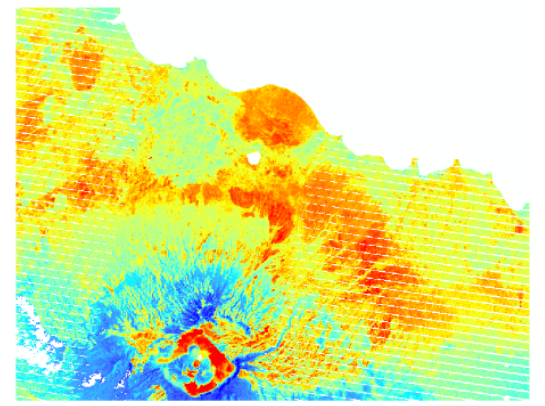

CWSI

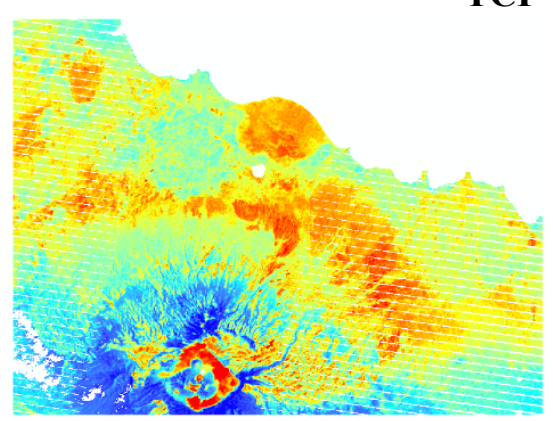

TCI

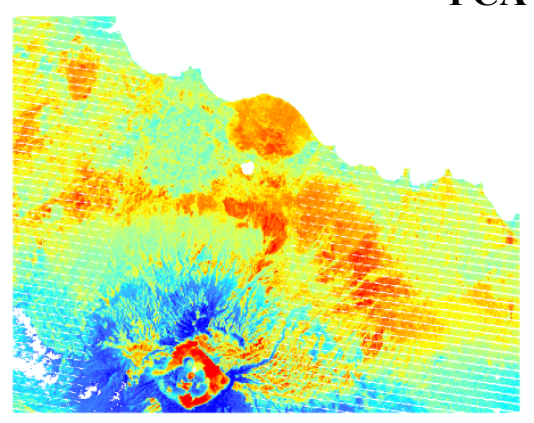

\section{October 2014}

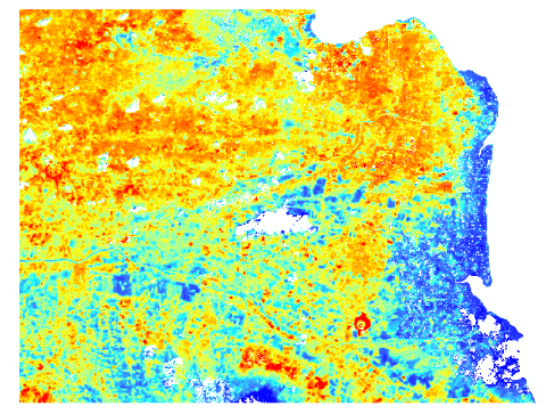

CWSI

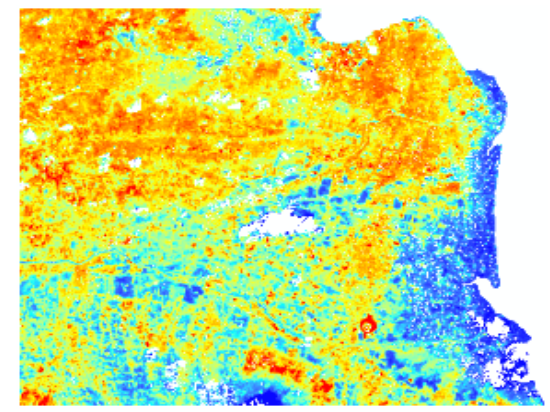

PCA

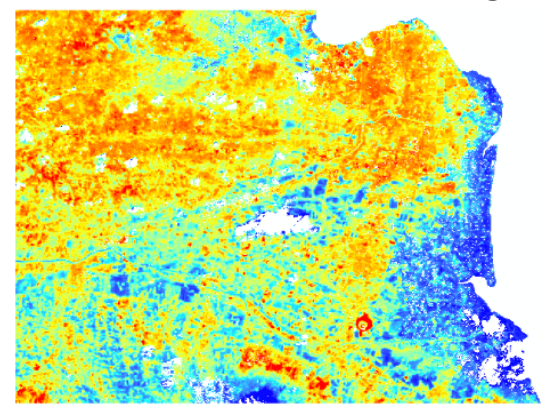

January 2015

CWSI

TCI

PCA 

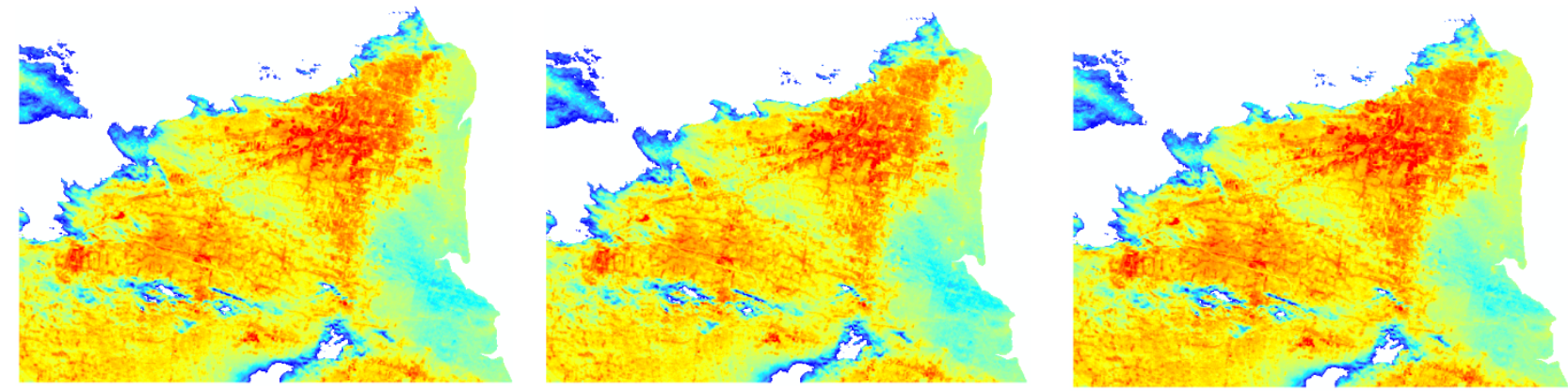

Figure 5. Result of TCI, CWSI, and PCA Processing data from Landsat 7 ETM+ and Landsat 8 OLI/TIRS image of Dry month and Wet months.

Processing data LST using Landsat influence from clouds and water. CWSI, TCI, and PCA give indicated increase and decrease for the drought but area around cloud have worse information. This result (figure. 5) make CWSI, TCI, and PCA not give more information for drought monitoring. That condition influenced many variable such as cloud, pre-processing (especially emissivity), need more algorithm to compare with other input like rainfall. That proved to detecting drought can use one algorithm. Processing data on October 2014 and January 2015 from Landsat 8 OLI/TIRS in one location. Surabaya city and around has indicated drought because of the influence of density of buildings, vehicle smoke, and also rooftop building. CWSI, TCI, and PCA are given information to drought monitoring with the multi-scale resolution with clear location and generate where the location is wet to dry in one scene image. This result for TCI proved Kogan [35] assumes because TCI has potential given information drought in a dry month with time-series data, but for a wet month, there is not a good condition. For CWSI is more relevant with condition soil moisture proved many areas they are not much water in surface but have more water in deep soil ( $>5$ centimeters). PCA conditions with new data from the different input algorithms given more information, but the result has a difference, not like Du et al. [13] and Son et al. [11]. Result of PCA similar to TCI and CWSI because two algorithms used a similar equation to extraction drought and LST only one difference equation to input for PCA. Two algorithm's input was given a more 50\% impact for results in the PCA technique because the final result of PCA did not have new information.

The multi-scale image proved to have correlation results to know spreads of drought even though of the three algorithms there is no more specified by providing information. All algorithms give similar results and have a positive correlation with drought distribution. One of the algorithms can be used as a reference for drought monitoring. CWSI, TCI, and PCA have differences expressed to know drought and have longer processing, but to monitor drought very fast expression algorithm LST can be seen as the phenomenon of drought without any algorithm. This condition needs more research to know the correlation between LST and the condition of drought directly.

\section{CONCLUSIONS}

Land Surface Temperature (LST) MODIS Terra and Landsat have a positive correlation of drought monitoring with three algorithms. That condition proved multi-scale image can be used for drought monitoring because multi-scale give different information with the detailed condition in any area although the distribution of drought same. LST based on three algorithms has high accuracy with SWA-Q and land cover emissivity.

Extraction of surface temperature with multi-scale necessary, especially temporal and spatial conditions becomes important to know the detail condition of drought. Processing with TCI, CWSI, and PCA proved they are the same indicated for distribution of drought and can be used one of them to know drought monitoring. All algorithms can be optimized if used by the conforming area. Drought monitoring indicated many factors have had to act to make different conditions such as buildup area and rooftop condition in some settlement. Maybe if using more algorithms and using different algorithms probabilistic PCA could give more information for drought monitoring.

\section{ACKNOWLEDGEMENTS}

The author thanks for staff and lecturer in the Faculty of Geography, Universitas Gadjah Mada especially remote sensing department helped and support this research finished. 


\section{REFERENCES}

[1] Lambin, E.F., and Ehrlich, D., "Land-cover changes in Sub-Saharan Africa (1982-1991): Application of a change index based on remotely sensed surface temperature and vegetation indices at a continental scale," Remote Sens. Environ. 61(2), 181-200 (1997).

[2] Puslitbang SDA, [The Drought's Problems and How to deal with them (Permasalahan Kekeringan dan Cara Mengatasinya)]. Bandung: Hidrologi Hall (Balai Hidrologi), Department of Settlements and Regional Infrastruture (Departemen Permukiman dan Prasarana Wilayah), 1-9 (2003).

[3] Ramanathan, V., Crutzen, P. J., Kiehl, J. T. and Rosenfeld, D., "Atmosphere: Aerosols, climate, and the hydrological cycle," Science (80-. ) 294( 5549), 2119-2124 (2001).

[4] Kalnay, E., and Cai, M., "Impact of urbanization and land-use change on climate," Nature 423(6939), 528-531 (2003).

[5] Wan, Z., Zhang, Y., Zhang, Q., and Li, Z. L., "Quality assessment and validation of the MODIS global land surface temperature," Int. J. Remote Sens. 25(1), 261-274 (2004).

[6] Chapin, F. S., Sturm, M., Serreze, M. C., McFadden, J. P., Key, J. R., Lloyd, A. H., .. Welker, J. M., "Role of land-surface changes in arctic summer warming," Science (80-. ) 310(5748), 657-660 (2005).

[7] Nugraha, A. S. A., "The Application Multi-Scale Remote Sensing for Mapping Drought Change (Case on East Java) (Pemanfaatan Citra Penginderaan Jauh Multi-Tingkat Untuk Pemetaan Perubahan Kekeringan (Kasus di Provinsi Jawa Timur))." Universitas Gadjah Mada (2016).

[8] Parwati and Suwarsono, "TVDI Model for Detecting a Drought on MODIS-Terra Data (Model Indeks TVDI ( Temperature Vegetation Dryness Index ) untuk Mendeteksi Kekeringan Lahan Berdasarkan Data Modis-Terra," Penginderaan Jauh 5, 35-44 (2008).

[9] Raharjo, P. D., "Remote Sensing and Geography Information System Technique for Identification Drought Potential" "(Teknik Penginderaan Jauh dan Sistem Informasi Geografis untuk Identifikasi Potensi Kekeringan)," Makara Teknol. 14(2), 97-105 (2010).

[10] Caccamo, G., Chisholm, L. A., Bradstock, R. A. and Puotinen, M. L., "Assessing the sensitivity of MODIS to monitor drought in high biomass ecosystems," Remote Sens. Environ. 115(10), 2626-2639 (2011).

[11] Son, N.T., Chen, C.F., Chen, C.R., Chang, L.Y., \& Minh, V.Q., "Monitoring agricultural drought in the lower mekong basin using MODIS NDVI and land surface temperature data," Int. J. Appl. Earth Obs. Geoinf. 18(1), 417-427 (2012).

[12] Patel, N.R., Parida, B.R., Venus, V., Saha, S.K., \& Dadhwal, V.K., "Analysis of agricultural drought using vegetation temperature condition index (VTCI) from Terra/MODIS satellite data," Environ. Monit. Assess. 184(12), 7153-7163 (2012).

[13] Du, L., Tian, Q., Yu, T., Meng, Q., Jancso, T., Udvardy, P., \& Huang, Y., "A comprehensive drought monitoring method integrating MODIS and TRMM data," Int. J. Appl. Earth Obs. Geoinf. 23(1), 245-253 (2013).

[14] Adiwicaksono, H., Sudarto. and Widianto., "The Spatial Distribution of Drought in Tuban using Remote Sensing and Geography Information System (Estimasi distribusi spasial kekeringan lahan di kabupaten tuban menggunakan penginderaan jauh dan sistem informasi geografis)," J. Tanah dan Sumberd. Lahan 1(2), 70-76 (2014).

[15] Nugraha, A. S. A., "The Application of Split-Windows Algorithm (SWA) Methods on Landsat 8 Using MODIS Terra Water Vapor (Pemanfaatan Metode Split-Windows Algorithm ( SWA ) pada Landsat 8 Menggunakan Data Uap Air MODIS Terra)," Geomatika 25(1), 9-16 (2019).

[16] Prasasti, I., Sambodo, K.A., and Carolita, I., "The Application MODIS-TERRA Data for Extraction Land Surface Temperature with Several Algorithms (Pengkajian Pemanfaatan Data TERRA-MODIS untuk Ekstraksi Data Suhu Permukaan Lahan (SPL) Berdasarkan Beberapa Algoritma)," Penginderaan Jauh 4(1), 1-8 (2007).

[17] U.S.G.S., "Landsat 7 Science Data User Handbook," (2010).

[18] Wu, J., Zhou, L., Liu, M., Zhang, J., Leng, S., \& Diao, C., "Establishing and assessing the Integrated Surface Drought Index (ISDI) for agricultural drought monitoring in mid-eastern China, " Int. J. Appl. Earth Obs. Geoinf. 23(1), 397-410 (2013).

[19] Bakornas, PB., [Introduction of Disaster Characteristics and Mitigation Efforts in Indonesia (Pengenalan karakteristik bencana dan upaya mitigasinya di Indonesia)], Mitigation Directorate (Direktorat Mitigasi), Lakhar BAKORNAS PB (2007).

[20] Kogan, F. N., "Droughts of the Late 1980s in the United States as Derived from NOAA Polar-Orbiting Satellite Data," Bulletin of the American Meteorological Society 76(5), 655-668 (1995a). 
[21] Amalo, L.F., Hidayat, R., Haris., "Comparison between remote-sensing-based drought indices in East Java," Proc. IOP 54, 1-7 (2017).

[22] Jackson R.D., Idso, R.B., Reginato, R.J. and Pinter P.J., "Canopy temperature as a crop water stress indicator," Water Resource Research 17, 1133-1138 (1981).

[23] Alderfasi, A.A. and Nielsen, D.C., "Use of crop water stress index for monitoring water status and scheduling irrigation in wheat," Agriculture Water Management 47, 69-75 (2001).

[24] Singh, R. P., Roy, S., Kogan, F., "Vegetation and temperature condition indices from NOAA AVHRR data for drought monitoring over India," Int. J. Remote Sensing 24, 4393-4402 (2013).

[25] Ghaleb, F., Mario, M., Sandra, A. N., "Regional landsat-based drought monitoring from 1982- 2004," Climate 3, 563-577 (2015).

[26] RezgarArabzadeh S.M., Kholoosi, M.M. and JavadBazrafshan, "Regional Hydrological Drought Monitoring Using Principal Components Analysis," ASCE Journal of Irrigation and Drainage Engineering 1, 142 (2015).

[27] Tian, M., Wang, P., and Khan, J., "Drought Forecasting with Vegetation Temperature Condition Index Using ARIMA Models in the Guanzhong Plain," Remote Sens. 8, 2-19 (2016).

[28] Sellam, V., Poovmmal, E. and Periasamy, P., "Estimating the impact of drought on crop yield Using principal component analysis," J. web Eng. 17(6), 1980-1992 (2018).

[29] RPJMD East Java. [Chapter II; Overview of the General State of the Region (BAB II; Gambaran Umum Kondisi Daerah)], East Province government (Pemerinah Provinsi Jawa Timur), 12-281 (2009).

[30]Li, A.L. and Becker, F., "Feasibility of land surface temperature and emissivity determination from AVHRR data, " Remote Sens. Environ. 43(1), 67-85 (1993).

[31]Qin, Z., Dall, G., Karni, A. and Berliner, P., "Derivation of split window algorithm and its sensitivity analysis for retrieving land surface temperature from NOAA-advanced very high resolution radiometer data, " $J$. Geophys. Res. 106670(16), 655-22 (2001).

[32] Wan, Z., [MODIS Land-Surface Temperature Algorithm Theoretical Basis Document (LST ATBD) Version 3.3.] Institute for Computational Earth System Science, University of California, Santa Barbara, 1-77 (1999).

[33]Rozenstein, O., Qin, Z., Derimian, Y., and Karnieli, A., "Derivation of land surface temperature for landsat-8 TIRS using a split window algorithm," Sensors (Switzerland) 14(4), 5768-5780 (2014).

[34] Kogan, F. N., "Application of vegetation index and brightness temperature for drought detection," Adv. Space Res. 15(11), 91-100 (1994a).

[35] Kogan, F. N., "Global Drought Watch from Space," Bulletin of the American Meteorological Society 78(4), 621636 (1997).

[36] Idso, S.B., Jackson, R.D., Pinter, P.J., Reginato, R.J., \& Hatfield, J.L., "Normalizing the stress-degree-day parameter for environmental variability," Agric. Meteorol. 24, 45-55 (1981).

[37] Moran, M. S., [Thermal infrared measurement as an indicator of plant ecosystem health. in: Thermal Remote Sensing in Land Surface Processes], CRC Press 257-282 (2004).

[38]Danoedoro, P., [Introduction Digital Remote Sensing (Remote Sensing Pengantar penginderaan jauh digital)]. Faculty of Geography (Fakultas Geografi), Universitas Gadjah Mada, Yogyakarta: Publisher Andi (Penerbit Andi) (2012).

[39] Richards, J.A. and Jia, X., [Remote Sensing Digital Image Analysis: An Introduction. Springer Verlag], Berlin, Germany (2006).

[40] Lasaponara, R., "On the use of principal component analysis (PCA) for evaluat- ing interannual vegetation anomalies from SPOT/VEGETATION NDVI temporal series," Ecological Modelling 194 (4), 429-434 (2006).

[41]Deng, J.S., Wang, K., Deng, Y.H., Qi, G.J., "PCA-based land-use change detection and analysis using multitemporal and multisensor satellite data," International Journal of Remote Sensing 29 (16), 4823-4838 (2008).

[42] Huang, F., Zhan, W., Voogt, J., Hu, L., Wang, Z.-H., Quan, J., .. Guo, Z., et al., "Temporal upscaling of surface urban heat island by incorporating an annual temperature cycle model: A tale of two cities," Remote Sensing of Environment 186 (2016).

[43] Levermore, G., Parkinson, J., Lee, K., Laycock, P., \& Lindley, S., "The increasing trend of the urban heat island intensity," Urban Climate 24 (2017).

[44] Sabins, F. F., [Remote Sensing: Principles and Application, Third Edition], United States of America: Waveland Press, Inc (2007).

[45] Tsou, J., Zhuang, J., Li, Y., \& Zhang, Y., "Urban Heat Island Assessment Using the Landsat 8 Data : A Case Study in Shenzhen and Hong Kong," Urban Science 1(10), 1-22 (2017). 
[46] Booth, N. and Smith, A. S., [Infrared Detectors], Goodwin House Publishers, New York \& Boston, 241-248 (1997).

Proc. of SPIE Vol. $11311113110 \mathrm{~A}-13$

Downloaded From: https://www.spiedigitallibrary.org/conference-proceedings-of-spie on 26 Apr 2023 Terms of Use: https://www.spiedigitallibrary.org/terms-of-use 